\title{
Műhely rendszerű termelés logisztikai kiszolgálásának automatizálási lehetőségei
}

\section{Automation Capabilities for the Logistics Service of Jobshop Production System}

\author{
B. FERENCZI ${ }^{1}$, P. NÉMETH ${ }^{2}$ \\ ${ }^{1}$ PhD hallgató, Széchenyi István Egyetem, Logisztikai és Szállítmányozási Tanszék, feba78@gmail.com \\ 2Egyetemi docens Széchenyi István Egyetem, Logisztikai és Szállítmányozási Tanszék, nemethp@sze.hu
}

\begin{abstract}
Absztrakt. A gyártási rendszerek egyik legfontosabb kiszolgáló alrendszere a technológiai fázisok közötti anyagmozgatást végző logisztikai rendszer, mely a gyártási struktúrától függő mértékben integrálódik. A rendkívül rugalmas mühelyrendszerü termelés sajátossága, hogy az anyagmozgatási rendszer jellemzően elkülönül és a mozgatási igények egymástól függetlenül, sztochasztikusan jelentkeznek, így az elvárt termelési cél eléréséhez az anyagmozgató rendszer rugalmassága is szükséges. A gyakorlatban ezért az anyagmozgatás szervezése, elvégzése jelenetös mértékben az emberi tényezőre van ráutalva. A jelen kutatás célja az anyagmozgatási tevékenység automatizálási lehetöségeinek feltárása ebben a különlegese termelési környezetben.
\end{abstract}

Kulcsszavak: Műhely rendszerú termelés, anyagmozgatás, automatizáció, optimalizáció, lineáris progrmozás

Abstract. One of the most important subsystems of manufacturing is the logistics system for transporting materials between technological phase. It is integrated depending on the production structure. The special feature of highly flexible workshop system production is that the material handling system is typically separate and the movement needs occur independently of each other, so the flexibility of the material handling system is required to achieve the expected production goal. In practice, therefore, the organization and execution of material handling is to a considerable extent dependent on the human factor. The purpose of this research is to explore the potential for automation of material handling activities in this particular production environment.

Keywords: shop production system, material handling, automatization, optimatization, linear programming

\section{Műhely rendszerű termelés anyagmozgatásának logisztikai problémái}

A magas hozzáadott értéket adó termelési rendszerek szerves, elválaszthatatlan része, az anyamozgatás, a munkadarabok termelő eszközökhöz és onnan történő mozgatása. Egyes 
termelési rendszerek esetén pl. a folyamat rendszerű gyártásban az anyagmozgató berendezések nagyfokúan integráltak, a futószalagok gyakorlatilag a termelő berendezések részét képezik, attól elválaszthatatlanok, egyúttal a gyártásközi készlet tárolási helyei is. A műhely rendszerű termelés operatív anyagmozgatási kiszolgálásra ellenben jellemző, hogy univerzális, az üzem által gyártandó termékek jellemzőihez igazodó de, független, rugalmas anyagmozgató berendezéseket igényel. Ezek lehetnek egyszerű kézi anyagmozgató eszközök, melyekkel a megmunkáló berendezésék kezelői végzik el a műhelyen belüli és a műhelyek közötti anyagmozgatási feladatokat. Amennyiben az üzem mérete, a műhelyek távolsága illetve a gyártandó termékek tömege ezt indokolja, nagy teherbírású és költséges anyagmozgató eszközöket és azok szakképzett kezelőit szükséges fenntartani. Ebben az esetben az anyagmozgatás szervezése már külön, specializált szervezetet igényelhet, ami akár több műhely illetve a teljes üzem összevont anyagmozgatási igényeit együttesen kezeli.

A funkcionális gyártási rendszer sajátossága, hogy amennyiben a termelő berendezések logisztikai kiszolgálása nem, vagy késéssel valósul meg, az a berendezések mellett tárolt készletek kifogyásával, vagy a puffer tárolók megtelésével a gyártó berendezés megállását okozza.

Emellett az műhely rendszerű termelés során az anyagmozgatási igények időbeli jelentkezése sem kiegyenlíthető, a különböző gyártó berendezések eltérő ciklusideje és termelési programja miatt.

Az anyagmozgatási kiszolgálás ezek alapján tehát közvetlenebb hatást gyakorol a termelési teljesítményre, mint más termelési rendszerekben, hatással van a berendezések termelő tevékenységgel tölthető idejére. A kiszolgálási színvonal és ezzel az üzemi teljesítmény egyik meghatározó tényezője tehát az anyagmozgató eszközök száma, ugyanakkor azok költsége negatív irányba befolyásolja a teljes vállalat gazdasági teljesítményét. Minden gazdasági profitra törekedő vállalat elemi érdeke, hogy a költségeit optimalizálja. Ebben az esetben két, egymástól független vezérlésű, mégis egymásra hatást gyakoroló rendszert szükséges összehangolni. Az optimum keresése egy logisztikai rendszerekre tipikusan jellemző trade-off helyzet [1], a magas anyagmozgatási kapacitás fenntartása költséget jelent, ugyanakkor rugalmas kiszolgálást és ezzel hatékonyabb termelést. Az anyagmozgatási kapacitáson megtakarított összegek ugyanakkor a termelési kapacitás kiesés miatti veszteségeit okozhatja. Ebben az esetben két egymással ellentétes meredekségű költség függvény összegének minimumpontján a gyártási kapacitás egy része várhatóan óhatatlanul kiszolgálásra várakozás formájában elveszik és időnként az anyagmozgató eszközök várakoznak a feladatra [2]

Az operatív anyagmozgatás irányítása során ez alapján lesznek olyan helyzetek, amikor egyszerre több az anyagmozgatási feladat, mint az eszköz, tehát priorizálni, sorba rendezni szükséges ezeket. A priorizálás célja hogy az anyagmozgatási szervezet operatív irányítása során az ismert feladatokat olyan sorrendben hajtsák végre, amivel a gyártó berendezések várakozási költsége elkerülhető, vagy minimális lesz. Ehhez első lépésben folyamatosan ismertnek kell lenni, hogy adott pillanatban milyen anyagmozgatási feladatok vannak, ezért feltételezzük, hogy egy valósidejű információs rendszer rendelkezésre áll. 
Az ismert feladatok elvégzési sorrendjének meghatározása lehetséges manuálisan, a targoncás, vagy a műszakvezetője által, de ebben az esetben az emberi tényező befolyásolni fogja a döntést. A korábbi tapasztalatok, egyéni preferenciák, vagy é en a motiváció meghatározó tényezői az emberi döntéseknek. Tekintve hogy N számú feladatot N! módon lehet sorba rendezni, várható hogy azonos helyzetben két ember nem fog ugyan úgy dönteni, illetve a már elvégzett döntések helyességének megítélése sem lesz nyilvánvaló. Ezért szükséges olyan egzakt paramétereken alapuló döntési rendszer kiépítése, ami a vállalati célokat figyelembe véve, általánosan elfogadott alapokon és módszerekkel priorizálja az egy időben jelentkező, azonos erőforrásokat igénylő feladatokat. Ezzel több cél is teljesíthető: rövid távon olyan anyagmozgatási feladat irányító rendszer hozható létre, ami nem szenved az emberi döntések hibáitól, hosszabb távon pedig utat nyit az automatizált anyagmozgatásnak.

\section{Automatizálás lehetősége a logisztikai kiszolgálásban}

“Az ember munkájának a megkönynítésér irányuló törekvések egyidősek az emberiséggel. Az élőmunka aránya a technikai fejlődés során folyamatosan csökken, ami a gépeknek köszönhető. Az ipari forradalom korától beszélhetünk automatizált berendezésekről (Jacquard lyukkártyás szövőgépe), de tömegesen a XX. században terjedtek el. Az automatizálás szoros kapcsolatban van az információgyújtéssel (mérés) és az információfeldolgozással (informatika)"[3]. A modern számítástechnikai eszközökön alapuló magas szintű automatizálás lehetősége alapozta meg a 4. ipari forradalmat. Ennek hatására olyan feladatok is automatizálhatóak, amikre korábban komplexicitásuk miatt nem volt lehetőség. Ennek további katalizátorai a folyamatosan emelkedő munkaerő költség és ezzel összefüggésben általánosan a munkaerő hiánya, illetve gyorsuló világ rövidülő reagálási igénye. A megbízhatóbb gépi munkavégzés az emberi hibák kiküszöbölésén keresztül költség megtakarítást is eredményez. Az emberi tényező kiváltása nem csak a gazdasági szükségszerűség, az emberekkel szemben a gépek nem küzdenek a monoton munkavégzéssel járó motivációvesztéssel, illetve szükségtelenné teszik a fizikailag megterhelő, esetleg balesetveszélyes feladatok emberi jelenléttel történő elvégzését is. Az alacsony képzettséget és/vagy monoton munkát munkakörök automatizálással történő kiváltása kikényszeríti, hogy a társadalom több erőforrást fektessen az automatizált rendszerek működtetését biztosító oktatásba, ezzel a társadalmi jólét is szükségszerūen növekszik.

A kulcsszó az automatizálásban az emberi beavatkozás nélkül történő feladat végrehajtás. $\mathrm{Az}$ automatizálás azonban nem hajtható végre egyik pillanatról a másikra, számos kutató foglalkozik munkásságában a különböző ipari automatizálási szintekkel (Level of Automatization LOA.) [4]

Ebben a cikkben terjedelmi okokból sem kerül sor az összes megközelítés felvázolására, de abban mindegyik megegyezik, hogy a kiinduló állapot a fizikai, kézzel történő munkavégzés és a technikai fejlődés hatására innen indulva folyamatosan nő a gépesítés és a gépi döntések foka és csökken az emberi munkavégzés igénye. Ezt a megközelítést alkalmaztuk az anyagmozgatás automatizáltsági szintjeinek felvázolására is. 


\begin{tabular}{|c|l|l|}
\hline Szint & Jellemzõ: & Példa: \\
\hline 0. & Minden tevékenység emberi izom erõvel történõ elvégzése. & Kézi rakodás, anyagmozgatás \\
\hline 1. & Kézi anyagmozgatás egyszerũ gépek segítségével & $\begin{array}{l}\text { Görgõk, emelök, csigák alkalmazása, } \\
\text { talicska. }\end{array}$ \\
\hline 2. & $\begin{array}{l}\text { Gépi erõvel végzett anyagmozgatás, ember a kezelési } \\
\text { feladatokat látja el. }\end{array}$ & Daru, targonca manuális vezérléssel \\
\hline 3. & $\begin{array}{l}\text { Gépi erõvel végzett anyagmozgatás és vezérlés, emberi } \\
\text { irányitással és bevatkozás probléma esetén }\end{array}$ & $\begin{array}{l}\text { PI. konvejor vagy láda szállitó sorok, } \\
\text { targoncán autómatikus szintbeállás, } \\
\text { pozicionálás. }\end{array}$ \\
\hline 4. & $\begin{array}{l}\text { Teljes mértékben gépi eszközök, ember programoz és feladat } \\
\text { forrásokat határoz meg, vezérlést a gép ezek alapján maga } \\
\text { végzi el. }\end{array}$ & $\begin{array}{l}\text { Pl. önjáró targoncák, komissiózó } \\
\text { autómaták }\end{array}$ \\
\hline
\end{tabular}

\section{1. táblázat. Az anyagmozagtás automatizálási fokai}

A logisztikai folyamatok egy vállalat meghatározó tevékenységei közé tartoznak, ugyanakkor jellemzően kiszolgáló, támogató funkciót töltenek be. Az egyik ilyen fontos támogató funkció, hogy a vállalati termelő folyamatokhoz nem vagy csak részben illeszkedő részeket standardizálja, lehetővé teszi a későbbi automatizálást, példa erre a felhasználásra szánt anyagok olyan egységrakatokba rendezése amiket már az automatizált eszközök kezelni tudnak. Ezek jellemzően olyan komplex tevékenységek, amik igénylik az emberi intelligenciát, probléma megoldást és döntést esetleg az emberi kéz ügyességét. É en ezért a logisztika automatizáltásági foka jelenleg jellemzően a 2 szinten áll, elmarad a termelési tevékenységekétől, sőt egyes esetekben a logisztikai folyamatok bővülnek a későbbi automatizálást lehetővé tevő előkészítő műveletek elvégzésével.

Ugyanakkor a logisztikai folyamatokra ugyan azok a kényszerítő erők hatnak mint a többi termelési folyamatra:, ezért vizsgálni szükséges, hogy ezek közül melyeket lehetséges automatizálni. Számításaink szerint egy targoncával végzett anyagmozgató rendszer költségeinek összetevői közül a humán költség 59\%-ot tesz ki, tehát az emberi munka kiváltása az emberi tényezőn kiiktatásán túl is gazdasági eredményt hozhat. A modern, vezeték nélküli kommunikáción, helymeghatározáson, képfelismerésen és mesterséges intelligencián alapuló vezérlések a olyan anyagmozgatási feladatok automatizálását is lehetővé teszik amik korábban elképzelhetetlenek voltak.

Cikkünkben azt vizsgáljuk, hogy a már említett műhelyrendszerű termelés körülményei között mely tevékenységek milyen szinten automatizálhatóak.

\section{A műhely rendszerű termelés körülményei között alkalmazható automatizálási megoldások}

A műhely rendszerű termelés anyagmozgatási feladatai az alábbi jellemző pontok között történhetnek: 
- Szállító jármü: amin az alapanyag beérkezik a telephelyre.

- Raktár: ahol az alapanyag tárolásra kerül

- Kiadási hely: az a terület, ahol a gyártásba kerülő tételeket előkészítik.

- Megmunkáló gép melletti tároló terület: az a hely, ahova az alapanyagokat tartalmazó egységrakat elhelyezésre kerül.

- Megmunkáló gép: az a hely és pozíció, ahol a munkadarabon a megmunkálást el lehet végezni, ez lehet maga a munkagép megmunkáló tere, de fejlett megmunkáló központok esetén annak adagoló tárja is.

- Megmunkáló gép melletti tároló terület: az a hely, ahova a kész munkadarabokat tartalmazó egységrakat elhelyezésre kerül.

- Raktári átvételi hely: az a terület, ahol a megmunkált, kész munkadarabok átvételre/csomagolásra kerülnek.

- Raktár: ahol a kész termékek az elszállításig, vagy a következő műveletig tárolásra kerülnek.

- Szállító jármú, amivel a kész munkadarabokat elszállítják.

Az 1 ábra mutatja a fenti felsorolás sematikus ábráját és hogy a feladatok mely pontok relációjában jelentkezhetnek. Az anyagmozgatási feladatok csoportosíthatóak aszerint, hogy a egyszerűek vagy komplexek-e, tehát igénylik az anyagmozgató gép kezelőjének emberi intelligenciáját vagy nem.

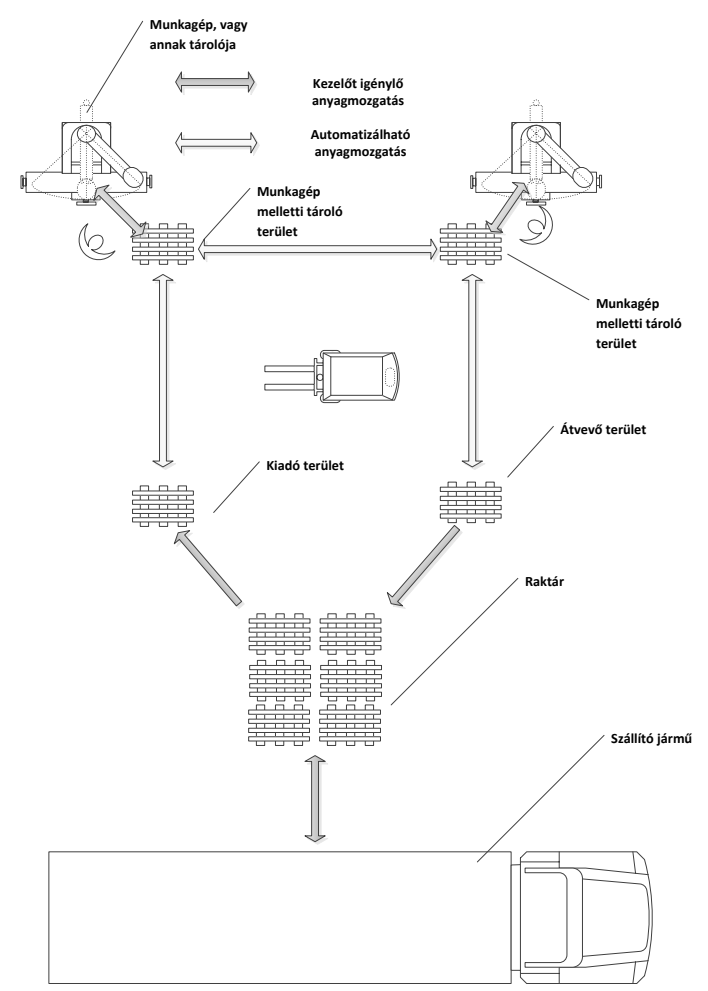

1. ábra. Az anyagmozgatásifeladatok sematikus ábrája 
Automatizálható anyagmozgatási feladat, ha meghatározott helyről meghatározott helyre kell standardizált módon csomagolt azonosított anyagot elszállítani. Ebben az esetben az automatikus anyagmozgató eszköztől elvárt funkciók:

- Tudjon tájékozódni az üzemi területen

- Ismerje fel az elszállítandó rakatot

- Tudja magát úgy pozícionálni, hogy a rakatot fel tudja venni.

- Tudjon az üzemben úgy közlekedni hogy nem okoz balesetet,

- Tudja a célhelyen a rakatot elhelyezni.

Ezeket a feladatokat egy kamerával ellátott, képfelismeréssel dolgozó, önvezető anyagmozgató eszköz már a ma ismert és elterjedt technológiával el tudja végezni. Ezzel ezek a feladatok automatizáltásga a 4-es szinten lesz.

Kezelőt igénylő anyagmozgatás: Nem automatizálható az anyagmozgatási feladat, hogyha a feladat elvégzése olyan komplex helyzet felismerést és döntést igényel, aminek a programozása nem kivitelezhető, vagy gazdaságilag nem éri meg. Ilyen feladatok a tehergépkocsik rakodása, a raktári átvételi, átcsomagolási és azonosítási tevékenységek. Ugyanakkor bármely feladat esetében lényeges, hogy a végrehajtási sorrendet és a végrehajtót egy olyan automatikus rendszer határozza meg, ami a vállalati cél szempontjából optimális döntést hoz. Ezzel technológialilag a kezelőt igénylő anyagmozgatások is a 3-as szintre lépnek.

\section{Az anyagmozgatási feladatokat irányító rendszer}

A globalizációs verseny folyamatos kihívásai arra ösztönzik a profit orientált vállalkozásokat, hogy mindenhol keressék a hatékonyság növekedés lehetőségeit. Az operációkutatás a katonai alkalmazásból egyre inkább az ipari környezetbe is átkerült és a kidolgozott módszerek (pl. lineáris programozás szimplex módszer) már a számítási kapacitás robbanásszerű növekedése előtt lehetővé tette az egzakt, matematikai alapon nyugvó döntéseket [5]. A számítástechnika fejlődése lehetővé teszi, hogy egyre bonyolultabb, összetettebb számítások kerüljenek elvégzésre egyre rövidebb idő alatt, ilyenek például a szimulációs módszerek. A gépi tanuláson alapuló mesterséges intelligencia megoldások az emberi elme számára átláthatatlanul nagy adat tömegből vett összefüggéseket is kezelni tudnak, illetve jó közelítéssel tudnak eseményeket előre jelezni [6]. Ezek a sokoldalú módszerek, mint például a neurális hálózatok vagy a fuzzy logikán alapuló kalkulációk számos tudomány területen is alkalmazhatóak [7], és az adott terület kutatói speciálisan adoptálják az általuk megoldandó problémákra [8],[9].

Az anyagmozgatási feladatokat automatizáltan irányító rendszer egy lehetséges struktúrája a 2. ábrán látható. Az egyes munkahelyekről, vagy egyéb anyagmozgatási pontoktól befutó igény információkat egy számítógép feldolgozza, hozzárendeli az anyagmozgató eszközökhöz, meghatározza az optimális végrehajtási sorrendet és monitorozza azok státuszát. Minden új feladat beérkezése esetén újra kalkulálja a feladatokat és szükség esetén újra osztja őket. 


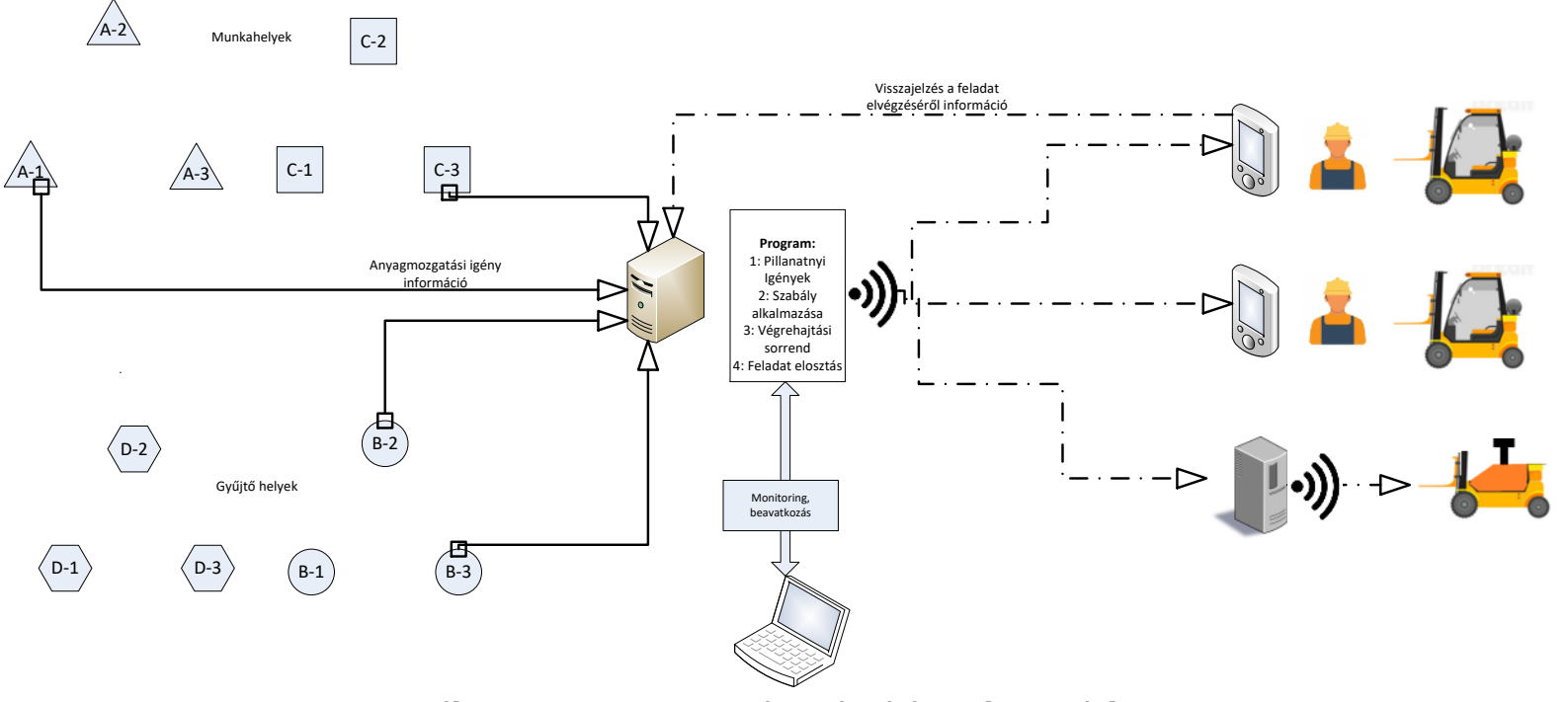

2. ábra. Az anyagmozgatást irányító rendszer vázlata

Kutatásaink alapján a műhelyrendszerű termelésben jelentkező anyagmozgatási feladatok az alábbi paraméterekkel leírhatóak, jellemezhetőek:

- Feladat végrehajtási helye (annak az adott gépnek vagy munkahelynek a megnevezése, ahol a kiszolgálási feladatot végre kell hajtani, a feladat azonosítója)

- Feladat végrehajtási idő normája (egy mérésekkel meghatározott idő érték, mely már tartalmazza az egyes munkahelyek közötti utazási időt is. Bár ez egy közelítő megoldás, nagyban megkönnyíti a számolások végrehajtását, ha nem kell az egyes kiszolgálandó munkahelye közötti utazási időt minden egyes relációra kiszámítani)

- Feladat határideje (ami után a gyártó berendezés megáll, és várakozási költség merül fel)

- Adott gyártó berendezés fajlagos várakozási idő költsége, más néven büntetési költség. (amennyiben az anyagmozgatási feladat határidején túl fejeződik be a végrehajtás)

A felsorolt paraméterekkel jellemzett feladatok eszközhöz allokálását és végrehajtási sorrendjét úgy szükséges meghatározni, hogy, azzal a lehető leg kevesebb várakozási költség merüljön fel.

A matematikai modell „N” számú feladatra és „k” számú kiszolgáló eszközre került kidolgozásra. Az egyes anyagmozgató eszközök eltérő tulajdonságokkal és képességekkel is bírhatnak.

A kiinduló állapotot, vagyis a rendszerben lévő feladatokat egy irányított gráf reprezentálja, az ahol a csúcsok az egyes berendezések kiszolgálásának befejezését, az élek súlya pedig az adott él végpontjában található berendezéshez történő utazás és a kiszolgálás idejének összegét jelentik.

A kiinduló állapotba egyetlen él sem mutat, a befejező állapotba mutató élek idő szükséglete 0 és csak oda mutatnak. A kiinduló csúcs a „0” sorszámot kapja, míg a befejezős csúcs a kiszolgálandó gépek száma +1 $(\mathrm{N}+1)$.

A feladat, hogy a gráf minden egyes, gép kiszolgálást jelentő csúcsa egyszer és csak egyszer bejárásra kerüljön. A kiinduló és az érkező csúcsokat minden targoncának be kell járnia. Ez a megközelítés megfeleltethető a többszörös utazó ügynök problémának (multiply travel 
salesman problem, mTSP), amikor is az ügyfélkört több ügynöknek kell úgy végig járnia, hogy minden ügyfél csak egyszer kerül meglátogatásra és a beutazott távolság minimalizálása a cél. [10]. A megoldási módszert is ezen alapul kiegészítve a késések költségével.

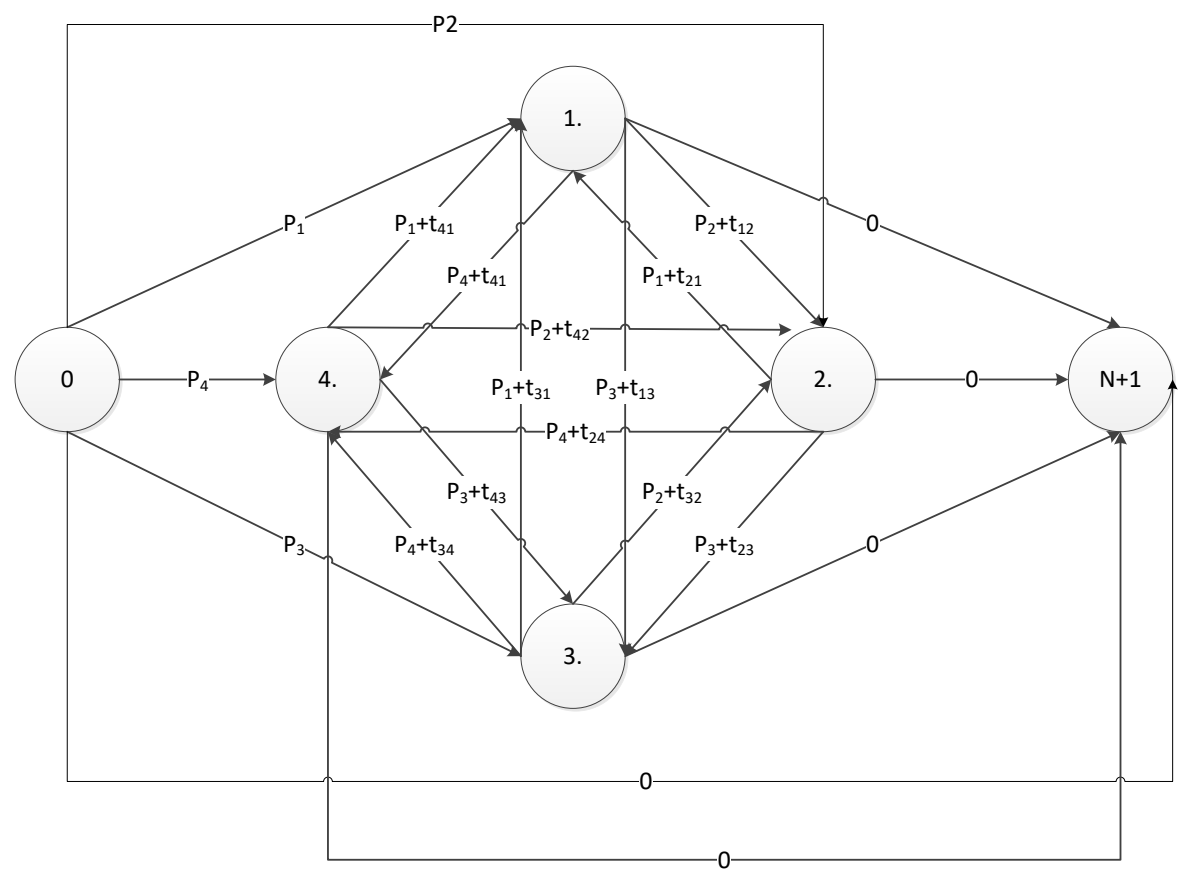

3. ábra. A feladat vázolására alkalmazott gráf vázlata

A végrehajtási sorrendet egy három dimenziós bináris mátrix határozza meg, ami megmutatja, hogy mely éleket melyik targoncák járnak be. A mátrix két dimenziója a kiinduló és a vég csúcsot reprezentálja.

A mátrix 3. dimenziója az egyes targoncáknak vagy automatikus anyagmozagtó eszközöknek feletethető meg. Minden eszközöhöz egy „szint” tartozik a 3. dimenzióban, ami az ábrán „K”-val került jelölésre. Minden eszköznek el kell jutnia a kiinduló csúcspontból a befejező csúcspontba. Ez a három dimenziós bináris mátrix a keresett változó. A feladat végrehajtásához minden pontot egyszer és csak egyszer be kell járni, ezért a változó mátrix sor és oszlop összegeinek 1nek kell lennie.

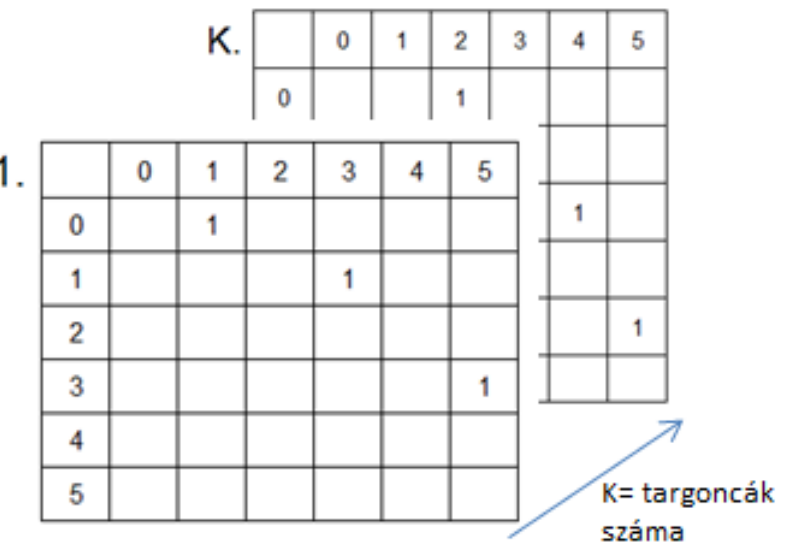

4. ábra. Az egyes targoncák számára az élek kiválasztását reprezentáló bináris mátrix vázlata 
A kompetencia mátrixban 1-esek reprezentálják azokat az útvonalakat, amiket az egyes anyagmozgató eszközök bejárhatnak. Ennek oka, hogy egyes eszközök nem végezhetnek el egyes feladatokat, tehát ott, ahol az adott targonca nem dolgozhat, az adott útvonalhoz 0 kerül hozzárendelésre. Ugyancsak 0 jelöli azokat az útvonalakat, amik logikailag nem járhatóak be, például az önmagukba vezetők, illetve a célból a startba vezető útvonalak.

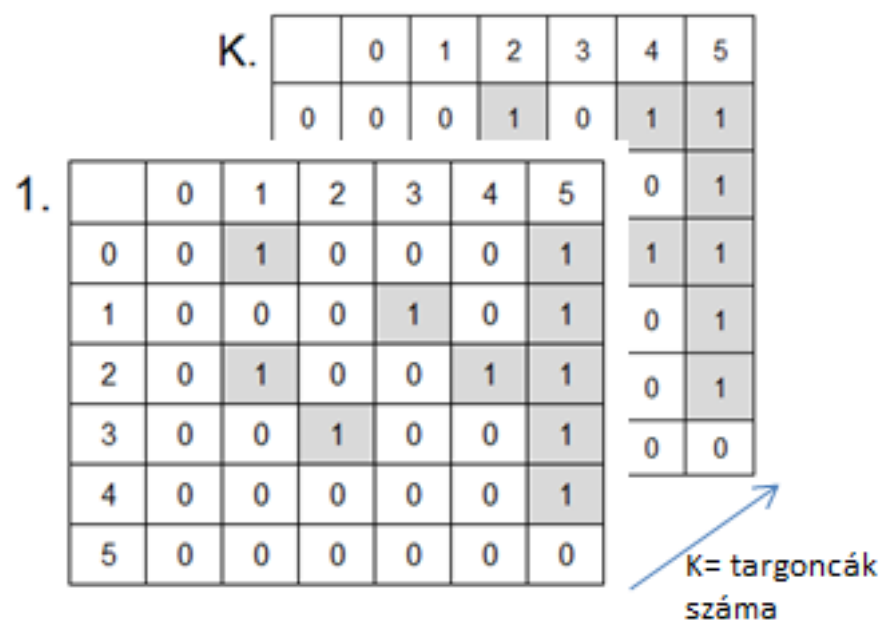

5. ábra. Az egyes targoncák számára egyes éleket kizáró "kompetencia mátrix" vázlata

További korlátozás, hogy a mátrix fóátlója 0 , mert a csúcsokból önmagukba nem vezet út. A kiinduló állapotból csak elfelé vezet út, míg a cél állapotba csak odafelé.

Az egyes feladatok esetében biztosítani kell, hogy az a targonca fejezze be, amelyik el kezdte. Ezt úgy lehet elérni, hogy annak a targoncának kell az adott csúcsot elhagyó élt is bejárni, amelyik a bemenő élet bejárta.

Az összköltség számítás képlete:

$D_{j}:$ a j.gép kiszolgálási határideje

$P_{j}$ : a j gép kiszolgálásának végrehajtási ideje

$C_{j}$ : a j gép állásnak fajlagos költsége

$S_{j}$ : a j gép kiszolgálásnak kezdési ideje $\left(S_{j} \geq 0\right)$

$L_{j}$ : a j gép kiszolgálásának késése $\left(L_{j} \geq 0\right)$

$$
L_{j}=\max \left\{0 ; D_{j}-\left(S_{j}+P_{j}\right)\right\}
$$

C: a teljes rendszer állásköltsége:

$$
C=\sum_{j=1}^{n} C_{j} * L_{j}
$$

A feladat így lineáris programozással megoldható. 


\section{További kutatások}

A kialakított matematikai modell alkalmas az olyan problémák kezelésére, ahol a feladatokat művelettel lehetséges végrehajtani , és ahol a feladatok végrehajtási ideje és a határidők eltérőek és a késés büntetése feladatonként eltérő. A modell ugyanakkor tovább bővíthető:

- Vizsgálandó, hogy amennyiben ismert az egyes targoncák pillanatnyi helye, azt hogyan lehet a modellbe beépíteni.

- Megoldást szükséges találni arra, hogyha a feladat sor újra tervezésre kerül, akkor a már kiosztott feladatokba a lehető leg kisebb mértékbe történjen változtatás.

- Alkalmazandó egy olyan rögzített időszak, amin belül a sorrendet már nem lehet változtatni, mert egyes (pl. komissiózási, megelőző anyagmozgatási) tevékenységek már folyamatban vannak

A felsorolt követelményeknek való megfelelés további kutatásokat és a matematikai modell bővítését igénylik. Feltételezésünk szerint a megalkotott modell megfelelő alapot jelent, és az igényeknek megfelelően bővíthető, kiegészíthető. Ezeken túl vizsgálandó, hogy a valós adatsorokon történő futtatásnak milyen időszükséglete van és hogy ez a gyakorlati, operatív alkalmazást lehetővé teszi-e. Ezen eredmények ismeretében vizsgálandó meg, hogy milyen heurisztikus módszerekkel lehet hatékonyabban ugyan ezt vagy közel ugyan ezt az eredményt elérni. Ehhez a lineáris programozási elven történő optimum számítási módszer egy lehetséges kontrollt jelent.

\section{6. Összefoglalás}

Cikkünkben azt vizsgáltuk, hogy a műhely rendszerű termelés változatos körülményei között az anyagmozgatás automatizált irányításának és az automatizált eszközök alkalmazásának milyen lehetőségei vannak. Megvizsgáltuk, hogy az említett termelési struktúrának milyen kiszolgálási követelményei vannak és hogy a feladatokat hogyan lehet komplexitás szerint csoportosítani.

Ez alapján úgy találtuk, hogy míg egyes feladat csoportokban nem lehet az emberi intelligenciát és probléma megoldást nélkülözni, az egyszerű, előre definiált pontok közötti szállítás esetében a mai technológiákkal is megvalósíthatóak az automatizált eszközök alkalmazása. Ugyanakkor a jelenleg alkalmazott jellemzően empirikus, tehát emberi tényezőt is tartalmazó alapokon nyugvó feladat allokáció is automatizálható, amennyiben rendelkezésre áll a valósidejű feladat követő és irányító rendszer.

Az egyes anyagmozgatási feladatok jellemezhetőek az utazási idővel, a végrehajtási idővel, ha feladat végrehajtásának határidejével és azzal a fajlagos költséggel ami felmerül hogyha a végrehatás a határidőn túl történik meg. A feladatot egy gráfként reprezentáltuk, melynek minden csúcsán egyetlen targoncának végig kell járnia úgy hogy az összes késéi költség minimális legyen. Az így vázolt matematikai modell már lineáris programozással megoldható, és 
a megoldás a gyakorlatban is kipróbálható, de további kutatások szükségesek a további tényezők figyelembe vételére.

Ezek alapján a műhely rendszerű termelés anyagmozgatásának automatizálására két, egymásra épülő lehetőség áll rendelkezésre: Alap megoldás az összes anyagmozgatási feladat digitális leképezése és a feladat végrehajtási sorrend a vállalat gazdasági optimumát veszi figyelembe, Erre épülhet, hogyha az alacsony komplexicitású feladatokat automatikus anyagmozgató eszközökkel is végre lehet hajtani. Ezekkel a megoldásokkal egyrészt az emberi tényező hatása csökken a feladat végrehajtás során, illetve a maga az emberi vagyis eszköz vezetési munka szükséglet is csökkenthető.

\section{Köszönetnyilvánítás}

A tanulmány a "Nemzetköziesítés, oktatói, kutatói és hallgatói utánpótlás megteremtése, a tudás és technológiai transzfer fejlesztése, mint az intelligens szakosodás eszközei a Széchenyi István Egyetemen" című (azonosító szám: EFOP-3.6.1-16-2016-00017) projekt keretében készült.

\section{Hivatkozások}

[1] Földesi, P. (2006): Logisztika I-II. Győr, Széchenyi István Egyetem.

[2] Ferenczi B., Németh P.:(2018):Funkcionális elrendezésü termelési rendszer logisztikájának automatizált irányítása. SzámOkt 2018 Tusnádfürdő, Románia, 176182

[3] Szabó T., (2011) Gépészeti automatizálás.Budapest, Eudutus Főiskola.

[4] Frohm, J., Lindström, V., Stahre, J., Winroth, M. (2008). Levels of automation in manufacturing. Ergonomia-an International journal of ergonomics and human factors, $30(3)$.

[5] Temesi, J., Varró, Z.:(2007), Operációkutatás. Budapest, AULA Kiadó

[6] Németh, P., Ladinig, T. B., \& Ferenczi, B.:(2016). Use of Artificial Neural Networks in the Production Control of Small Batch Production. International Conference on Artificial Intelligence (ICAI) (p. 237).

[7] Singh, H., Gupta, M. M., Meitzler, T., Hou, Z. G., Garg, K. K., Solo, A. M., \& Zadeh, L. A.(2013): Real-life a lications of fuzzy logic. Advances in Fuzzy Systems

[8] Bilkay, O., Anlagan, O., Kilic, S.E. (2004): Job shop scheduling using fuzzy logic, The International Journal of Advanced Manufacturing Technology, April 2004, Volume 23, Issue 7-8, . 606-619

[9] Lilik, F., Nagy. S., Kóczy, L T. (2018): On Combination of Wavelet Transformation and Stabilized KH Interpolation for Fuzzy Inferences Based on High Dimensional Sampled 
International Journal of Engineering and Management Sciences (IJEMS) Vol. 5. (2020). No. 1

DOI: $10.21791 /$ IJEMS.2020.1.18

Functions, Interactions Between Computational Intelligence and Mathematics Cham (Németország), Németország : Springer International Publishing, (2018) . 31-42.

[10] Bektas, T. (2006). The multiple traveling salesman problem: an overview of formulations and solution procedures. OMEGA: The International Journal of Management Science 34(3), 209-219. 